\title{
KEDUDUKAN ALAT BUKTI DIGITAL DALAM PEMBUKTIAN CYBERCRIME DI PENGADILAN
}

\author{
Cahyo Handoko ${ }^{1}$ \\ Universitas Muhammadiyah Surakarta \\ Program Magister Ilmu Hukum \\ Email: Cahyohandoko36@gmail.com
}

\begin{abstract}
$B$ asically every law made by legislators is the answer to the question of public law at the time of the establishment of the law. Should legal developments in line with the development of society, so that when people change or grow then the law should be changed to arrange all the developments taking place in an orderly manner in the growth of modern society, because globalization has been the driver of the birth of the era of information technology. This study aimed to describe the profile of digital evidence in cyber crime cases, knowing the position of digital evidence in cases of cyber crime. The theory used in this research is a progressive legal theory with empirical juridical methods using qualitative data analysis, kind of his research is a descriptive study. The conclusion of this study, System proofs and evidences under Article 184 Criminal Procedure Code can reach cybercrime evidence for crimes classified as new criminal offenses. A search for evidence of unconventional tools such as witness testimony and expert witnesses, as well as letters and instructions shift from conventional towards electronic will be able to ensnare cybercriminals. Law No. 11 of 2008 on Information and Electronic Transactions on Article 5 has been clearly stated that electronic information is a valid legal evidence in the form of electronic information and / or electronic documents and / or printout.
\end{abstract}

\section{Keywords: Crime, Electronic Transactions, Cyber Crime.}

\begin{abstract}
Abstrak
$P$ ada dasarnya setiap undang-undang yang dibuat oleh pembuat undang-undang merupakan jawaban hukum terhadap persoalan masyarakat pada waktu dibentuknya undang-undang tersebut. Perkembangan hukum seharusnya seiring dengan perkembangan masyarakat, sehingga ketika masyarakatnya berubah atau berkembang maka hukum harus berubah untuk menata semua perkembangan yang terjadi dengan tertib di tengah pertumbuhan masyarakat modern ${ }^{2}$, karena globalisasi telah menjadi pendorong lahirnya era teknologi informasi. ${ }^{3}$ Penelitian ini bertujuan untuk mendiskripsikan profil alat bukti digital pada perkara cyber crime, mengetahui kedudukan alat bukti digital pada perkara cyber crime. Teori yang digunakan dalam penelitian ini merupakan teori hukum progresif dengan metode penelitian yuridis empiris dengan menggunakan analisis data secara kualitatif, jenis penelitian nya merupakan penelitian deskriptif. Kesimpulan dari penelitian ini, Sistem pembuktian dan alat-alat bukti berdasarkan Pasal 184 KUHAP mampu menjangkau pembuktian untuk kejahatan cybercrime yang tergolong tindak pidana baru. Penelusuran terhadap alat-alat bukti konvensional seperti keterangan saksi dan saksi ahli, juga pergeseran surat dan petunjuk dari konvensional menuju elektronik akan mampu menjerat pelaku cyber crime. Undang-Undang No. 11 tahun 2008 tentang Informasi dan Transaksi Elektronik pada Pasal 5 telah secara jelas
\end{abstract}

1 Mahasiswa Pascasarjana Magister Ilmu Hukum Universitas Muhammadiyah Surakarta.

2 Budi Suhariyanto, Tindak Pidana Teknologi Informasi (Cybercrime) Urgensi dan Pengaturan Celah Hukumnya, Jakarta: Raja Grafindo Persada, 2012.Hlm ix.

3 Ibid. Hlm 1. 
menyebutkan bahwa Informasi Elektronik merupakan alat bukti hukum yang sah berupa informasi elektronik dan/atau dokumen elektronik dan/atau hasil cetaknya.

Kata Kunci: Tindak Pidana, Transaksi Elektronik, Cyber Crime.

\section{Pendahuluan}

\section{Latar Belakang}

Pada dasarnya setiap undang-undang yang dibuat oleh pembuat undang-undang merupakan jawaban hukum terhadap persoalan masyarakat pada waktu dibentuknya undangundang tersebut. Perkembangan hukum seharusnya seiring dengan perkembangan masyarakat, sehingga ketika masyarakatnya berubah atau berkembang maka hukum harus berubah untuk menata semua perkembangan yang terjadi dengan tertib di tengah pertumbuhan masyarakat modern ${ }^{4}$, karena globalisasi telah menjadi pendorong lahirnya era teknologi informasi. ${ }^{5}$

Seiring dengan perkembangan kebutuhan masyarakat di dunia, teknologi informasi memegang peran penting, baik di masa kini maupun di masa mendatang. Setidaknya ada dua hal yang yang membuat teknologi informasi dianggap begitu penting dalam memacu pertumbuhan ekonomi dunia. Pertama, teknologi informasi mendorong permintaan atas produk-produk teknologi informasi, kedua adalah memudahkan transaksi bisnis terutama bisnis keuangan disamping bisnis-bisnis lainnya. ${ }^{6}$

Teknologi informasi dengan sendirinya juga merubah perilaku masyarakat. Perkembangan teknologi informasi telah menyebabkan dunia menjadi tanpa batas dan menyebabkan perubahan sosial yang sangat cepat. Sehingga dapat dikatakan teknologi informasi saat ini menjadi pedang bermata dua, Karena selain memberikan kontribusi bagi peningkatan kesejahteraan, kemajuan, dan peradaban manusia, sekaligus menjadi sarana efektif perbuatan melawan hukum. ${ }^{7}$

Perbuatan melawan hukum dalam Undang-Undang Nomor 11 Tahun 2008 Tentang Informasi dan Transaksi Elektronik, kejahatan dalam teknologi informasi disebut dengan Cyber Crime. Cyber Crime adalah jenis kejahatan yang berkaitan dengan pemanfaatan sebuah teknologi informasi dan komunikasi tanpa batas, serta memiliki sebuah karakteristik yang kuat dengan sebuah rekayasa teknologi yang mengandalkan tingkat keamanan yang tinggi, dari sebuah informasi yang disampaikan dan diakses oleh pengguna internet. ${ }^{8}$

Dalam Pasal 35 Undang-Undang Nomor 11 Tahun 2008 tentang ITE telah dijelaskan bahwa "Setiap Orang dengan sengaja dan tanpa hak atau melawan hukum melakukan manipulasi, penciptaan, perubahan, penghilangan, pengrusakan Informasi Elektronik dan/atau Dokumen Elektronik dengan tujuan agar Informasi Elektronik dan/atau Dokumen Elektronik tersebut dianggap seolah-olah data yang otentik".

Di Indonesia banyak kasus yang berkaitan dengan kejahatan dunia maya (cybercrime). Menurut Wakil Ketua Bidang Monitoring dan Keamanan Jaringan ID-SIRTII/CC, Muhammad Salahudin mengatakan saat ini kasus pelanggaran cyber crime tahun 2014 hingga awal april telah mencapai sekitar 1.000 kasus. Jumlah ini terus meningkat tiap tahunnya mencapai 100 persen. Di 2010 hanya 100 kasus setahun, 2011 naik 200 kasus, 2012 menjadi 400 kasus. ${ }^{9}$ Dalam praktik di Indonesia, tindak pidana dengan menggunakan komputer sejak dahulu merupakan jenis kejahatan yang sulit untuk diklasifikasikan sebagai tindak pidana. ${ }^{10}$ Permasalahan hukum

4 Budi Suhariyanto, Tindak Pidana Teknologi Informasi (Cybercrime) Urgensi dan Pengaturan Celah Hukumnya, Jakarta: Raja Grafindo Persada, 2012.Hlm ix.

5 Ibid. Hlm 1.

6 Loc.Cit.

7 Ibid. Hlm. 2.

8 Agus Tri P.H. Cyber Crime dalam Perspektif Hukum Pidana,Skripsi, 2010,Surakarta:UMS. Hlm. 10.

9 Jatimprov, 2014, Tiap Tahun Kasus Cyber Crime Naik 100 Persen,(2-4-2014) dalam http://www.jatimprov.go.id/site/ tiap-tahun-kasus-cyber-crime-naik-100-persen/. Di unduh senin 23 Juni 2014 Pukul 06.00 WIB

10 Maskun, Kejahatan Siber Cyber Crime, Jakarta:Kencana Prenada Media Group, 2013, Hlm. 62. 
yang seringkali dihadapi adalah ketika terkait dengan penyampaian informasi, komunikasi dan/ atau transaksi secara elektronik, khususnya dalam hal pembuktian dan hal yang tekait dengan perbuatan hukum yang dilaksanakan melalui sistem elektronik. ${ }^{11}$

Salah satu contoh kasus cyber crime yang terjadi di Surakarta, yang mana dalam pembuktiannya mengalami kendala dalam kasus pembobol sebuah password email, yang mana seseorang tersebut menderita kerugian hingga miliaran rupiah, karena email tersebut menjadi alat transaksi di perusahaan tersebut. Dalam hal ini seorang hakim menghadirkan seorang saksi ahli, yang dipercaya untuk mengidentifikasi malware yang di tanam dalam laptop korban akan tetapi saksi ahli dari pelapor/korban tidak dapat membuktikannya sehinga terdakwa diputus bebas oleh hakim. ${ }^{12}$

Dengan demikian dalam prakteknya, pembuktian dalam hukum pidana merupakan sesuatu yang sangat vital perannya, mengingat dalam KUHAP (Kitab Undang-Undang Acara Pidana) peran suatu bukti sangat berpengaruh kepada pertimbangan hakim. Setiap kendala yang muncul membuat penegak hukum menjadi bingung untuk menyimpulkan suatu perkara dalam bidang Teknologi Informasi, yang mana bentuk barang bukti berbentuk digital.

\section{Perumusan Masalah}

1. Bagaimana profil alat bukti dalam kasus cyber crime?

2. Bagaimana kedudukan alat bukti dalam kasus cyber crime?

\section{Metode Penelitian}

\section{Metode Pendekatan}

Metode Pendekatan yang digunakan oleh Penulis dalam penelitian ini adalah pendekatan yuridis empiris yaitu pendekatan secara langsung dengan terjun ke lapangan. Dengan demikian metode penelitian yuridis empiris dapat memberikan gambaran bagaimana Kedudukan Alat Bukti Digital dalam kasus Cyber Crime.

\section{Jenis Penelitian}

Jenis Penelitian yang digunakan penulis dalam penelitian ini adalah penelitian yang bersifat deskriptif yaitu untuk memberikan gambaran selengkap-lengkapnya mengenai proses pembuktian tindak pidana cyber, Penelitian Deskriptif sendiri dimaksudkan untuk meberikan data yang seteliti mungkin tentang manusia, keadaan atau gejala-gejala lainnya. Penulis didalam penelitian ini menggambarkan mengenai bagaimana Pembuktian dalam kasus Cyber Crime.

\section{Hasil Penelitian dan Pembahasan}

\section{Profil alat bukti digital dalam kasus cybercrime}

Pembuktian merupakan tahap yang menentukan dalam proses perkara, karena dari hasil pembuktian dapat diketahui benar atau tidaknya suatu dakwaan atau tuntutan tersebut dengan menunjuk pada alat bukti. Alat bukti adalah segala sesuatu yang ada hubungannya dengan suatu perbuatan, dimana dengan alat-alat bukti tersebut, dapat dipergunakan sebagai bahan pembuktian guna menimbulkan keyakinan hakim atas kebenaran adanya suatu tindak pidana yang telah dilakukan terdakwa. ${ }^{13}$ Pembuktian sendiri ialah perbuatan membuktikan, membuktikan berarti memberi atau memperlihatkan bukti, melakukan sesuatu sebagai kebenaran, melaksanakan, menandakan, menyaksikan, dan meyakinkan. ${ }^{14}$

11 Penjelasan Undang-Undang Nomor 11 Tahun 2008 tentang Informasi dan Transaksi Elektronik, Paragraf 2.

12 Putusan No.20/Pid.sus/2011/PN.SKA

13 Politkum, Pengertian alat bukti yang sah, dalam http://politkum.blogspot.com/2013/05/pengertian-alat-bukti-yang-sahdalam.html. diakses pada tanggal 21 Nopember 2014 pukul 14.36

14 Eddy O.S. Hiariej, Teori \& Hukum Pembuktian, Jakarta: Erlangga, 2012, Hal 3. 
Pengaturan mengenai alat bukti dalam cyber crime diatur dalam :

a. KUHAP.

b. Undang-Undang No. 11 tahun 2008 tentang Informasi dan Transaksi Elektronik.

Dalam sistem pembuktian yang dianut dalam KUHAP Pasal 183 KUHAP dijelaskan "hakim tidak boleh menjatuhkan pidana kepada seseorang kecuali apabila dengan sekurangkurangnya dua alat bukti yang sah ia memperoleh keyakinan bahwa suatu tindak pidana benarbenar terjadi dan bahwa terdakwa lah yang bersalah melakukannya". Masalah pembuktian ini cukup memegang peranan penting dalam menangani kejahatan siber, hal ini perlu menjadi catatan sebab bukti elektronik telah menjadi media perantara baru bagi pelaksanaan suatu tindak kejahatan. ${ }^{15}$

Dalam Konteks pembuktian, rumusan delik dalam suatu undang-undang, selain merupakan perwujudan asas legalitas, juga memiliki fungsi unjuk bukti. Artinya, yang harus dibuktikan oleh jaksa penuntut umum di pengadilan adalah unsur-unsur dalam suatu rumusan delik yang didakwakan kepada tersangka. Berikut merupakan perbandingan dari Undang-Undang yang mengatur tentang bukti elektronik :

\begin{tabular}{ll}
\hline $\begin{array}{l}\text { Kitab Undang-Undang Hukum Acara } \\
\text { Pidana (KUHAP) }\end{array}$ & $\begin{array}{l}\text { Undang-Undang No. } 8 \text { tahun 2011 } \\
\text { tentang Informasi dan Transaksi } \\
\text { Elektronik }\end{array}$ \\
\hline Keterangan Saksi & Keterangan Saksi \\
Keterangan Ahli & Keterangan Ahli \\
Surat & Surat \\
Petunjuk & Petunjuk \\
Keterangan Terdakwa & - \\
\hline
\end{tabular}

Berdasarkan KUHAP dan Undang-Undang No. 11 tahun 2008 tentang Informasi dan Transaksi Elektronik, dalam tindak pidana cyber crime alat bukti yang dapat dipergunakan adalah sebagai berikut :

a. Keterangan Saksi

Definisi saksi dan definisi keterangan saksi secara tegas diatur dalam KUHAP, berdasarkan Pasal 1 angka 26 KUHAP dinyatakan "Saksi adalah orang yang dapat memberikan keterangan guna kepentingan penyidikan, penuntutan, dan peradilan tentang perkara pidana yang ia dengar sendiri, ia lihat sendiri, dan ia alami sendiri". Sementara itu Keterangan Saksi menurut Pasal 1 angka 27 KUHAP, "keterangan saksi adalah salah satu alat bukti dalam perkara pidana yang berupa keterangan dari saksi mengenai suatu peristiwa pidana yang ia dengar sendiri, ia lihat sendiri, dan ia alami sendiri dengan menyebut alasan dari pengetahuannya itu". Saksi dituntut untuk memberikan keterangan yang sebenarnya atau paling tidak mendekati dari peristiwa yang dia lihat, untuk memberikan pemahaman pada hakim dalam memberikan putusan kepada pelaku tindak pidana.

Sedangkan saksi dalam perkara cybercrime melibatkan orang yang melihat dan menguasai dunia maya yang keterangannya dapat dijadikan pertimbangan hakim dalam mengungkap fakta di persidangan, hal ini diatur dalam Pasal 7 Undang-Undang No. 11 tahun 2008 tentang Informasi dan Transaksi Elektronik yang berbunyi "Setiap orang yang menyatakan hak, memperkuat hak yang telah ada, atau menolak hak orang lain berdasarkan adanya Informasi Elektronik dan/atau Dokumen Elektronik harus memastikan bahwa Informasi Elektronik dan/atau Dokumen Elektronik yang ada padanya berasal dari

15 Khairul Anam, Hacking VS Hukum Positif \& Islam, Yogyakarta:Sunan Kalijaga Pers, 2010. Hal 62. 
sistem Elektronik yang memenuhi syarat berdasarkan peraturan perundang-undangan”.

Dalam Undang-Undang No. 11 tahun 2008 tentang Informasi dan Transaksi Elektronik, seorang saksi dapat menggunakan media elektronik untuk memberikan keterangan nya, sehingga tidak harus datang langsung ke pengadilan sehingga bisa melalui media komunikasi berdasarkan pada Pasal 44 Undang-Undang No. 11 tahun 2008 tentang Informasi dan Transaksi Elektronik menyebutkan "Alat bukti penyidikan penuntutan dan pemeriksaan sidang pengadilan menurut ketentuan undang-undang ini adalah sebagai berikut : alat bukti sebagaimana dimaksud dalam ketentuan perundang-undangan, alat bukti berupa Informasi Elektronik dan/atau Dokumen Elektronik sebagaimana dimaksud dalam Pasal 1 angka 1 dan angka 4 serta Pasal 5 ayat (1), ayat (2), dan ayat (3)”.

Dalam penyidikan tindak pidana cyber crime ada 3 (tiga) fase yang digunakan oleh penyidik, saksi mata disuruh menceritakan segala informasi yang ia lihat dan informasi lainnya yang berkaitan dengan kejahatan. Polisi mencari tersangka berdasarkan informasi yang diperoleh dari saksi mata dan mencari rekam jejak dari orang yang berpotensi sebagai tersangka. Polisi meminta saksi mata untuk mengidentifikasi pelaku dari sejumlah calon tersangka yang dimiliki polisi secara langsung dengan mempertunjukan calon tersangka tersebut. ${ }^{16}$

Jika keterangan beberapa saksi yang berdiri sendiri-sendiri tentang suatu kejadian atau keadaan dapat digunakan sebagai suatu alat bukti yang sah apabila keterangan saksi itu memiliki hubungan satu dengan yang lain sedemikian rupa sehingga dapat membenarkan adanya suatu kejadian atau keadaan tertentu.

Dalam pengaturan Undang-Undang No. 11 tahun 2008 tentang Informasi dan Transaksi Elektronik, seorang saksi tidak diwajibkan datang ke muka persidangan, sebagaimana telah dijelaskan dalam Undang-Undang No. 11 tahun 2008 tentang Informasi dan Transaksi Elektronik. Pada Pasal 44 menyebutkan "Alat bukti penyidikan penuntutan dan pemeriksaan sidang pengadilan menurut ketentuan undang-undang ini adalah sebagai berikut : alat bukti sebagaimana dimaksud dalam ketentuan perundang-undangan, alat bukti berupa Informasi Elektronik dan/atau Dokumen Elektronik sebagaimana dimaksud dalam Pasal 1 angka 1 dan angka 4 serta Pasal 5 ayat (1), ayat (2), dan ayat (3)”.

Dalam prosedur pemberian keterangan saksi di pengadilan dapat melalui teleconference dengan menunjuk pada Pasal 1 angka 1 dan angka 4 Undang - Undang No. 11 tahun 2008 tentang Informasi dan Transaksi Elektronik yang berbunyi “ angka 1 : Informasi elektronik adalah satu atau sekumpulan data elektronik, termasuk tetapi tidak terbatas pada tulisan, suara, gambar, peta, rancangan, foto, electronic data interchange (EDI), surat elektronik, telegram, teleks, telecopy atau sejenisnya, huruf, tanda, angka, kode akses, simbol, atau perforasi, yang telah diolah yang memiliki arti atau dapat dipahami oleh orang yang mampu memahaminya, angka 4: Dokumen elektronik adalah setiap Informasi Elektronik yang dibuat, diteruskan, dikirimkan, diterima, atau disimpan dalam bentuk analog, digital, elektromagnetik, optikal, atau sejenisnya, yang dapat dilihat, ditampilkan, dan/atau didengar melalui komputer atau sistem elektronik, termasuk tetapi tidak terbatas pada tulisan, suara, gambar, peta, rancangan, foto atau sejenisnya, huruf, tanda, angka, Kode akses, simbol atau perforasi yang memiliki makna atau arti atau dapat dipahami oleh orang yang mampu memahaminya". Walau melalui teleconference keterangan saksi itu tetap sah menurut hukum dengan menunjuk pada Pasal 5 ayat (1) Undang-Undang No. 11 tahun 2008 "Informasi elektronik dan/atau Dokumen Elektronik dan/atau hasil cetaknya merupakan alat bukti yang sah".

Dengan demikian, berdasarkan pembahasan diatas, memberikan gambaran bahwa keterangan saksi dalam KUHAP yang telah diatur dalam Pasal 1 angka 27 KUHAP. Yang pada intinya menyatakan bahwa keterangan saksi merupakan sebuah alat bukti dalam

16 Eddy O.S. Hiariej, Teori \& Hukum Pembuktian, Jakarta:Erlangga, 2012, Hal 103. 
perkara pidana yang berupa keterangan yang diberikan langsung oleh saksi, mengenai suatu peristiwa pidana yang ia dengar sendiri, ia lihat sendiri, dan ia alami sendiri dengan menyebut alasan dari pengetahuannya itu". Saksi tersebut dalam memberikan keterangannya wajib untuk hadir dalam persidangan yang dibuka untuk umum, sebagaimana sesuai dengan penjelasan dalam Pasal 160 KUHAP.

b. Keterangan Ahli

Keterangan ahli menurut pasal 1 angka 28 KUHAP adalah keterangan yang diberikan oleh seorang yang memiliki keahlian khusus tentang hal yang diperlukan untuk membuat terang suatu perkara pidana guna kepentingan pemeriksaan.

Keterangan ahli memang terkait dengan alat bukti untuk membentuk keyakinan hakim dalam memutus suatu perkara cybercrime, biasanya di ambil dari seorang guru besar dan seorang pemikir. ${ }^{17}$ Didalam Pasal 186 KUHAP menyatakan bahwa "keterangan seorang ahli ialah apa yang seorang ahli nyatakan di sidang pengadilan". Menurut penjelasan Pasal 186 KUHAP dibuat dengan mengingat sumpah di waktu ia menerima jabatan atau pekerjaan.

Merujuk pada ketentuan dalam KUHAP, keahlian dari seorang yang memberikan keterangan ahli tidak hanya berdasarkan pengetahuan yang ia miliki melalui pendidikan formal, namun keahlian itu juga dapat diperoleh berdasarkan pengalamannya. Karena didalam KUHAP, tidak ada persyaratan kualifikasi seorang ahli harus memenuhi jenjang akademik tertentu.

Keterangan ahli biasanya bersifat umum berupa pendapat atas pokok perkara pidana yang sedang disidangkan atau yang berkaitan dengan pokok perkara tersebut. Ahli tidak diperkenankan memberikan penilaian terhadap kasus yang sedang di sidangkan. Oleh karena itu, pertanyaan terhadap ahli biasanya bersifat hipotesis atau pernyataan yang bersifat umum. Ahli pun tidak boleh memberikan penilaian terhadap salah atau tidaknya terdakwa berdasarkan fakta persidangan yang ditanyakan padanya.

Jadi, dalam perkara cyber crime seorang ahli di tuntut untuk memberikan pengertian tentang pengungkapan kejadian perkara yang terjadi di dunia maya sepanjang pengetahuan nya, karena saksi ahli merupakan orang yang berkompeten di bidangnya, hal ini dijelaskan pada pasal 1 ayat (1) Undang-Undang No. 11 tahun 2008 tentang Informasi dan Transaksi Elektronik yang berbunyi "Informasi Elektronik adalah satu atau sekumpulan data elektronik, termasuk tetapi tidak terbatas pada tulisan, suara, gambar, peta, rancangan, foto, electronik data interchange (EDI), surat elektronik, telegram, teleks, telecopy, atau sejenisnya, huruf, tanda, angka, kode akses, simbol, atau perforasi yang telah diolah yang memiliki arti atau dapat dipahami oleh orang yang mampu memahaminya". Istilah "dapat dipahami oleh orang yang mampu memahaminya" merupakan tuntutan kepada saksi ahli untuk menerjemahkan kejadian yang diungkapkan oleh saksi dan terdakwa, dan keterangan ahli berbentuk laporan yang dicatat dalam berita acara pemeriksaan.

c. Surat

Menurut Pasal 187 KUHAP, Surat sebagaimana tersebut pada Pasal 184 ayat (1) huruf c, dibuat atas sumpah jabatan atau dikuatkan dengan sumpah, jenis surat yang dimaksud adalah:

1) Berita acara dan surat lain dalam bentuk resmi yang dibuat oleh pejabat umum yang berwenang atau yang dibuat di hadapannya, yang memuat keterangan tentang kejadian atau keadaan yang didengar, dilihat atau yang dialaminya sendiri, disertai dengan alasan yang jelas dan tegas tentang keterangannya itu;

2) Surat yang dibuat menurut ketentuan peraturan perundang-undangan atau surat yang dibuat oleh pejabat mengenal hal yang termasuk dalam tata laksana yang

17 Samardi, Keterangan Ahli, dalam https://samardi.wordpress.com/tag/keterangan-ahli/, diakses pada tanggal 21 Nopember 2014, pukul 15.08 WIB 
menjadi tanggung jawabnya dan yang diperuntukkan bagi pembuktian sesuatu hal atau sesuatu keadaan.

3) Surat keterangan dari seorang ahli yang memuat pendapat berdasarkan keahliannya mengenai sesuatu hal atau sesuatu keadaan yang diminta secara resmi dan padanya;

4) Surat lain yang hanya dapat berlaku jika ada hubungannya dengan isi dari alat pembuktian yang lain.

Berdasarkan Pasal 187 KUHAP diuraikan tentang alat bukti surat yang terdiri dari 4 (empat) butir. Berdasarkan Undang-Undang Informasi dan Transaksi Elektronik, Informasi elektronik dan atau dokumen elektronik dan atau hasil cetakannya merupakan alat bukti hukum yang sah. Informasi Elektroni dan atau Dokumen Elektronik berikut hasil cetakannya merupakan perluasan alat bukti yang sah menurut hukum acara. Dokumen Elektronik tidaklah dapat dijadikan alat bukti jika terhadap suatu surat, Undang-Undang menentukan harus dibuat dalam bentuk tertulis, termasuk pula akta notaris atau akta yang dibuat oleh pejabat pembuat akta. Dalam hal surat-surat tidak memenuhi persyaratan untuk dinyatakan sebagai bukti surat, surat-surat tersebut dapat dipergunakan sebagai petunjuk. Akan tetapi, mengenai dapat atau tidaknya surat dijadikan alat bukti petunjuk, semuanya diserahkan kepada pertimbangan hakim.

Jadi alat bukti surat yang dipakai dalam pembuktian cyber crime merupakan alat bukti yang sah sepanjang itu sesuai dengan sistem elektronik yang di atur dalam undang-undang yang mengaturnya, karena alat bukti surat terlebih yang berbentuk digital dapat dirubah keasliannya dalam hitungan detik dan tanpa harus memegang barang bukti yang ditunjukan di persidangan. Dengan demikian dapat diketahui bahwa surat merupakan alat bukti yang sah sesuai dengan pasal 5 ayat (1) Undang-Undang No. 11 tahun 2008 tentang Informasi dan Transaksi Elektronik Serta merujuk pada pertimbangan hakim yang bersangkutan.

d. Petunjuk

Pasal 188 KUHAP ayat (1) yang berbunyi "Petunjuk adalah perbuatan, kejadian atau keadaan, yang karena persesuaiannya, baik antara yang satu dengan yang lain, maupun dengan tindak pidana itu sendiri, menandakan bahwa telah terjadi suatu tindak pidana dan siapa pelakunya”.

Alat bukti petunjuk merupakan otoritas penuh dan subjektivitas hakim yang memeriksa perkara tersebut. Hakim dalam mengambil kesimpulan tentang pembuktian sebagai suatu petunjuk haruslah menghubungkan alat bukti yang satu dengan yang lain. Penilaian atas kekuatan pembuktian suatu petunjuk dalam setiap keadaan tertentu dilakukan oleh hakim setelah ia mengadakan pemeriksaan. Tegasnya, syarat-syarat petunjuk sebagai alat bukti harus mempunyai perseuaian satu sama lain atas perbuatan yang terjadi. Selain itu, keadaan-keadaan tersebut berhubungan satu sama lain dengan kejahatan yang terjadi dan berdasarkan pengamatan hakim yang diperoleh dari keterangan saksi, surat dan keterangan terdakwa.

Menurut Adami Chazawi mengungkapkan persyaratan suatu petunjuk adalah sebagai berikut $:^{18}$

1) Adanya perbuatan, kejadian, dan keadaan yang berseuaian. Perbuatan, Kejadian, dan Keadaan merupakan fakta-fakta yang menunjukan tentang telah terjadinya tindak pidana, menunjukkan terdakwa yang melakukan, dan menunjukan terdakwa bersalah karena melakukan tindak pidana tersebut.

2) Ada dua persesuaian, yaitu bersesuaian antara masing-masing perbuatan, kejadian, dan keadaan satu sama lain ataupun bersesuaian antara perbuatan, kejadian, atau keadaan dengan tindak pidana yang didakwakan.

18 Eddy O.S. Hiariej, Teori \& Hukum Pembuktian, Jakarta:Erlangga, 2012, Hal 110. 
3) Persesuaian yang demikian itu menandakan atau menunjukan adanya dua hal, yaitu menunjukan siapa pelakunya. Unsur ini merupakan kesimpulan bekerjanya proses pembentukan alat bukti petunjuk, yang sekaligus merupakan tujuan dari alat bukti petunjuk.

4) Hanya dapat dibentuk melalui tiga alat bukti, yaitu keterangan saksi, surat, dan keterangan terdakwa. Sesuai dengan asas minimum pembuktian seperti pada Pasal 183 KUHAP, selayaknya petunjuk juga dihasilkan dari minimal dua alat bukti yang sah.

Oleh karena itu, alat bukti petunjuk ini baru digunakan dalam hal alat-alat bukti yang ada belum dapat membentuk keyakinan hakim tentang terjadinya tindak pidana dan terdakwalah yang melakukannya. Dari kata adanya persesuaian dapat disimpulkan bahwa sekurang-kurangnya harus ada dua petunjuk untuk mendapatkan bukti yang sah. Petunjuk yang ditemukan dalam penyidikan, merupakan alat bukti yang sah sesuai dengan Pasal 5 ayat (1) Undang-Undang No. 11 tahun 2008 tentang Informasi dan Transaksi Elektronik, sehingga apabila petunjuk tersebut dalam bentuk digital, maka dapat digunakan sebagai alat bukti dalam persidangan.

e. Keterangan Terdakwa

Penerapan pembuktian perkara pidana yang diatur dalam hukum acara pidana selamanya tetap diperlukan sekalipun terdakwa mengakui tindak pidana yang didakwakan kepadanya. ${ }^{19}$ Terdakwa dalam Pasal 1 Butir 15 KUHAP adalah seseorang tersangka yang dituntut, diperiksa, dan diadili di sidang pengadilan. Menurut Pasal 189 ayat (1) KUHAP, "Keterangan terdakwa adalah apa yang terdakwa nyatakan di sidang tentang perbuatan yang dilakukan atau yang ia ketahui sendiri atau ia alami sendiri". Keterangan terdakwa yang diberikan di luar sidang dapat digunakan untuk membantu menemukan bukti di sidang, asalkan keterangan itu didukung oleh suatu alat bukti yang sah sepanjang mengenai hal yang didakwakan kepadanya.

Keterangan terdakwa hanya dapat digunakan terhadap dirinya sendiri, hal ini menunjuk pada Pasal 189 ayat (4) KUHAP "Keterangan terdakwa saja tidak cukup untuk membuktikan bahwa ia bersalah melakukan perbuatan yang didakwakan kepadanya”. Bahwa seorang terdakwa tidak dibebani kewajiban dalam pembuktian, jadi keterangan terdakwa yang sah adalah keterangan ia nyatakan di sidang pengadilan.

Dengan merujuk pada arti kata bukti, yakni sesuatu yang menyatakan kebenaran suatu peristiwa, Penulis berpendapat bahwa arti penting pembuktian adalah mencari kebenaran atas suatu peristiwa. Dalam konteks hukum, arti penting pembuktian adalah mencari kebenaran suatu peristiwa hukum. Peristiwa hukum adalah peristiwa yang mempunya akibat hukum.

Jadi, dapat dimengerti bahwa pembuktian dilihat dari perspektif hukum acara pidana, yakni ketentuan yang membatasi sidang pengadilan dalam usaha mencari dan mempertahankan kebenaran, baik oleh hakim, penuntut umum, terdakwa maupun penasehat hukum, semuanya terikat pada ketentuan dan tata cara, serta penilaian alat bukti yang ada pada Undang-Undang No. 11 tahun 2008 tentang Informasi dan Transaksi Elektronik.

\section{Kedudukan alat bukti digital dalam perkara cyber crime}

Dalam menangani kasus cyber crime aparat penegak hukum harus memperhatikan mengenai alat bukti digital yang digunakan oleh pelaku dalam melakukan perbuatannya. Karena alat bukti digital tersebut mempunyai kedudukan yang sangat penting dalam rangka proses pembuktian di Persidangan Pengadilan. Dari alat bukti digital tersebut yang nantinya juga akan menentukan apakah perbuatan yang dilakukan oleh terdakwa benar bersalah menurut hukum.

19 Yahya Harahap dalam www.HukumOnline.com/klinik/detail/lt52e015b3902e6/kekuatan-pengakuan-terdakwa-dipersidangan.html, diakses pada tanggal 28 pebruari 2015, jam 23.06 WIB. 
Dalam hal ini penulis akan melakukan analisis terhadap 3 Putusan Pengadilan (2 Putusan Pengadilan Negeri Surakarta dan 1 Putusan Pengadilan Negeri Sleman) mengenai perkara tindak pidana cyber crime. Dari analisis putusan yang dilakukan penulis, sehingga akan dapat diketahui mengenai kedudukan alat bukti digital dalam perkara tindak pidana cyber crime. Analsis tersebut akan diuraikan penulis sebagaimana berikut dibawah ini :

\begin{tabular}{|c|c|c|c|}
\hline Kualifikasi & & Putusan Pengadilan & \\
\hline No. Putusan & $\begin{array}{l}\text { 20/Pid.Sus/2011/ } \\
\text { PN.Ska }\end{array}$ & $\begin{array}{l}\text { 79/Pid.Sus/2013/ } \\
\text { PN.Ska }\end{array}$ & $\begin{array}{l}\text { 476/Pid.B/2013/ } \\
\text { PN. Sleman }\end{array}$ \\
\hline Terpidana & Syarif Bin Syech Salim & $\begin{array}{l}\text { Anthon Wahjupramono, } \\
\text { S.H, M.Hum. }\end{array}$ & $\begin{array}{l}\text { Herman Joseph bin le } \\
\text { Hie Soeng }\end{array}$ \\
\hline Tindak Kejahatan & $\begin{array}{lr}\text { Pembobolan } & \text { Email/ } \\
\text { Mengakses } & \text { komputer } \\
\text { tanpa ijin. } & \end{array}$ & $\begin{array}{l}\text { Penyebaran ancaman } \\
\text { melalui Pesan Instan } \\
\text { (SMS) }\end{array}$ & $\begin{array}{lr}\text { Tanpa } & \text { hak } \\
\text { mentransmisikan } \\
\text { informasi elektronik } \\
\text { yang memiliki muatan } \\
\text { yang melanggar } \\
\text { kesusilaan }\end{array}$ \\
\hline Dakwaan & $\begin{array}{l}\text { Pasal } 30 \text { ayat (1) Jo } \\
\text { Pasal 46 ayat (1) } \\
\text { Undang-Undang RI } \\
\text { Nomor } 11 \text { tahun } 2008 \\
\text { Tentang Informasi dan } \\
\text { Transaksi Elektronik }\end{array}$ & $\begin{array}{l}\text { Pasal } 29 \text { Jo Pasal } 45 \text { ayat } \\
\text { (3) Undang-Undang } \\
\text { Republik Indonesia No. } \\
11 \text { Tahun } 2008 \text { tentang } \\
\text { Informasi dan Transaksi } \\
\text { Elektronik; }\end{array}$ & $\begin{array}{l}\text { Pasal } 45 \text { ayat (1) Jo } \\
\text { Pasal } 27 \text { ayat (1) } \\
\text { U n d a n g - Un d a n g } \\
\text { Republik Indonesia No. } \\
\text { 11 Tahun } 2008 \text { tentang } \\
\text { Informasi dan Transaksi } \\
\text { Elektronik }\end{array}$ \\
\hline Putusan & $\begin{array}{l}\text { Menjatuhkan pidana } \\
\text { terhadap terdakwa } \\
\text { dengan pidana penjara } \\
\text { selama } 1 \text { (satu) tahun } \\
\text { dikurangi selama masa } \\
\text { penangkapan dan masa } \\
\text { penahanan yang telah } \\
\text { dijalani terdakwa, dan } \\
\text { denda sebesar Rp. } \\
1.000 .000,- \text { (satu juta } \\
\text { rupiah) subsidair } 1 \\
\text { (satu) bulan kurungan. }\end{array}$ & 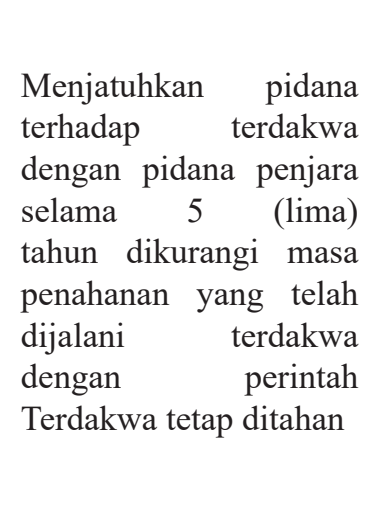 & $\begin{array}{l}\text { Menjatuhkan pidana } \\
\text { terhadap Herman } \\
\text { Joseph Bin le Hie Soeng } \\
\text { pidana penjara selama } 8 \\
\text { (delapan) bulan }\end{array}$ \\
\hline
\end{tabular}




\begin{tabular}{|c|c|c|c|}
\hline Kualifikasi & & Putusan Pengadilan & \\
\hline & Keterangan Saksi: & Keterangan Saksi: & \\
\hline & Umar Edrus AL Habsyi & Sumartono Hadinoto & \\
\hline & Ali Muladawileh & Iwan Setiawan & \\
\hline & Ahmad Idrus & Arlita Handayani Binti & \\
\hline & Suherman & Paryono & \\
\hline & Herman & Rizki Agung Perkasa & \\
\hline & Abdulah Aldjufri & Bin Ateng Efendi & \\
\hline & & Pratiwi Binti Slamet & \\
\hline & & Hariyono & \\
\hline & & Saksi Ririn Wijayanti & \\
\hline & Keterangan Ahli: & Binti Sutarno & Keterangan Saksi: \\
\hline & Sapto Hermawan & & Arik Susilo \\
\hline & Makhali Arsyad & Keterangan Ahli: & Agung Kusmiyanto \\
\hline & Trisna Samodra & Toto Tri Kusuma, R, & Sri Handayani \\
\hline & & & Agustina \\
\hline & Petunjuk: & Drs. Supardjo, M.Hum & Purwantari \\
\hline & Percakapan Kepada & Dr. Mudzakkir, S.H, & \\
\hline & pelanggan nya melalui & $\begin{array}{l}\text { M.H. } \\
\text { DR Henry Subiakto }\end{array}$ & Keterangan Ahli: \\
\hline & $\begin{array}{l}7 \text { (tujuh) bendel Nota } \\
\text { pembelanjaan dari }\end{array}$ & Slamet Uliandi & $\begin{array}{l}\text { Bisyron Wahyudi, S. Si, } \\
\text { MT }\end{array}$ \\
\hline & toko IAKA Shop pada & Petunjuk: & \\
\hline & alamat toko tersebut & 1 (satu) lembar list data, & Alat Bukti Digital: \\
\hline & tercantum alamat : $\mathrm{Jl}$. & 1 (satu) box XP Mentari & 1(satu) buah CPU server \\
\hline \multirow[t]{24}{*}{ Alat Bukti } & Double Six No. $80 \mathrm{X}$ & Smartphone & 1 (satu) buah CPU \\
\hline & Legian Kuta Bali $\mathrm{Ph} /$ & ditandatangani oleh $\mathrm{G}$. & biling \\
\hline & Fax : 62-361-734880 & Sinta Setyandari anak & 3(tiga) buah CPU biling \\
\hline & dan Email : iaka & dari Winarsanto dan. & No. 10,15 dan 17 \\
\hline & kuta@yahoo.com yang & 2 (dua) lembar kwitansi & 1 (satu) unit Flashdisk \\
\hline & digunakan sejak tahun & No. 129136 dari CV. & tanpa tutup merk \\
\hline & 2003 hingga 2009; & $\begin{array}{l}\text { Dayamitra Selindo } \\
\text { tertanggal } 26 \text { Nopember }\end{array}$ & $\begin{array}{l}\text { Multitech warna biru } 1 \\
\text { Unit Mouse }\end{array}$ \\
\hline & Alat Bukti Digital: & 2012 kepada GRA & 1 (satu) Unit Monitor \\
\hline & Laptop Merk Toshiba & Cellular warna kuning & 1 (satu) Unit Mouse \\
\hline & Satelite L20 System & dan merah. & 1 (satu) buah keyboard \\
\hline & Unit Model Nomor & Rekaman CCTV dari & 1 (satu) buah swit \\
\hline & PSL201-00X011 warna & Ambarukmo Plaza & Data dan File Konten \\
\hline & hitam. & Yogyakarta & Porno \\
\hline & Laptop Merk Axio & 6 (enam) Pesan singkat/ & \\
\hline & Notebook Computer & SMS yang mengancam & \\
\hline & Model : M54 V Product & dan memaki ditujukan & \\
\hline & Code M541V warna & pada H.M Lukminto. & \\
\hline & Hitam. & & \\
\hline & Iaka.Kuta@ & Alat Bukti Digital: & \\
\hline & yahoo.com (email & $\mathrm{S}$ e $\mathrm{p}$ e $\mathrm{r}$ a $\mathrm{ng} \mathrm{k} \mathrm{kt}$ & \\
\hline & milik Umar Edrus) & Smartphone BB Dakota & \\
\hline & 1 (satu) buah CD & type 9900 NO. IMEI & \\
\hline & Aplikasi & 3585.67 .04 .281426 .5 & \\
\hline & Spyerasser & warna hitam & \\
\hline
\end{tabular}

Dalam 3 (tiga) putusan di atas dapat dikategorikan dalam tindak pidana cyber crime karena ketiga putusan tersebut melanggar Undang-Undang No. 11 tahun 2008 tentang Informasi dan Transaksi Elektronik, yang pertama putusan No. 20/Pid.Sus/2011/PN.Ska yang didakwa dengan Pasal 30 ayat (1) Jo Pasal 46 ayat (1) Undang-Undang RI Nomor 11 tahun 2008 tentang Informasi dan Transaksi Elektronik, yang kedua Putusan No. 79/Pid.Sus/2013/PN.Ska yang 
didakwa dengan Pasal 29 Jo Pasal 45 ayat (3) Undang-Undang RI No. 11 tahun 2008 tentang Informasi dan Transaksi Elektronik, dan yang terakhir Putusan No. 476/Pid.B/2013/PN. Sleman yang didakwa Pasal 45 ayat (1) Jo Pasal 27 ayat (1) Undang-Undang RI No. 11 tahun 2008 tentang Informasi dan Transaksi Elektronik.

Pertimbangan hakim dalam mengungkap fakta di persidangan dengan menggunakan alat bukti digital ialah pada Pasal 5 ayat (1) Undang-Undang No. 11 tahun 2008 tentang Informasi dan Transaksi Elektronik menjelaskan "Informasi Elektronik dan/atau Dokumen Elektronik dan/atau hasil cetaknya merupakan alat bukti hukum yang sah". Untuk mengungkap alat bukti digital maka hakim memerlukan saksi ahli dalam menjelaskan alat bukti tersebut seperti yang tercantum pada Pasal 1 angka 1 dan angka 4 yang menjelaskan "angka 1 : Informasi Elektronik adalah satu atau sekumpulan data elektronik, termasuk tetapi tidak terbatas pada tulisan, suara, gambar, peta, rancangan, foto, electronic data interchange (EDI), surat elektronik (electronic mail), telegram, teleks, telecopy atau sejenisnya, huruf, tanda, angka, Kode Akses, simbol, atau perforasi yang telah diolah yang memiliki arti atau dapat dipahami oleh orang yang mampu memahaminya, angka 4 : Dokumen Elektronik adalah setiap Informasi Elektronik yang dibuat, diteruskan, dikirimkan, diterima, atau disimpan dalam bentuk analog, digital, elektromagnetik, optikal, atau sejenisnya, yang dapat dilihat, ditampilkan, dan/atau didengar melalui Komputer atau Sistem Elektronik, termasuk tetapi tidak terbatas pada tulisan, suara, gambar, peta, rancangan, foto atau sejenisnya, huruf, tanda, angka, Kode Akses, simbol atau perforasi yang memiliki makna atau arti atau dapat dipahami oleh orang yang mampu memahaminya". Sehingga dapat kita ketahui kedudukan alat bukti digital dalam ketiga putusan diatas adalah bahwa dalam pengungkapan fakta di persidangan dalam rangka menemukan kebenaran materiil, Majelis Hakim membutuhkan alat bukti digital dalam perkara cyber crime dan peran saksi ahli dalam menguatkan peran kedudukan alat bukti digital tersebut, karena dalam Pasal 1 angka 1 dan angka 4 Undang-Undang No. 11 tahun 2008 menjelaskan bahwa Informasi Elektronik dan Dokumen Elektronik hanya bisa dipahami oleh orang yang mampu memahaminya, orang yang mampu memahaminya berarti mempunyai keahlian dalam bidang Informasi dan Transaksi Elektronik, dalam hal ini disebut saksi ahli, yang didalam putusan diatas saksi ahli diperintahkan untuk menjelaskan kedudukan alat bukti digital kepada majelis hakim. Karena kedudukan alat bukti digital dalam putusan diatas mempengaruhi pertimbangan hakim untuk membuat putusan.

Berdasarkan 3 Putusan cyber crime di atas dapat diketahui alat bukti digital diatas yang digunakan adalah :

1. Laptop

2. Email

3. $\mathrm{CD}$

4. Software (Uniblue Spyerasser)

5. Smartphone

6. CPU (Central Processing Unit)

7. Flashdisk

8. Data

9. Konten Film Porno

10. Rekaman CCTV

11. SMS

Alat bukti digital adalah Informasi Elektronik dan/atau Dokumen Elektronik yang memenuhi persyaratan formil dan persyaratan materiil yang diatur dalam Undang-Undang No. 11 tahun 2008 tentang Informasi dan Transaksi Elektronik. Barang bukti dapat dikatakan alat bukti digital karena berbentuk Informasi Elektronik dan/atau Dokumen Elektronik yang sesuai dengan kriteria Pada Pasal 1 angka 1 dan angka 4 Undang-Undang No. 11 tahun 2008 yang 
meliputi tulisan, suara, gambar, peta, rancangan, foto, electronic data interchange (EDI), surat elektronik (electronic mail), telegram, teleks, telecopy atau sejenisnya, huruf, tanda, angka, Kode Akses, simbol, atau perforasi yang telah diolah yang memiliki arti atau dapat dipahami oleh orang yang mampu memahaminya dan bentuk analog, digital, elektromagnetik, optikal, atau sejenisnya, yang dapat dilihat, ditampilkan, dan/atau didengar melalui Komputer atau Sistem Elektronik, termasuk tetapi tidak terbatas pada tulisan, suara, gambar, peta, rancangan, foto atau sejenisnya, huruf, tanda, angka, Kode Akses, simbol atau perforasi yang memiliki makna atau arti atau dapat dipahami oleh orang yang mampu memahaminya, yang dalam putusan diatas merupakan alat bukti yang mempunyai kedudukan untuk menjelaskan suatu tindak cyber crime yang mungkin dilakukan oleh tersangka, sehingga alat bukti digital ini memperjelas fakta yang terjadi dengan didukung alat bukti lainnya.

Dapat diketahui jenis-jenis alat bukti digital yang telah di jelaskan dalam pasal 1 angka 1 dan angka 4 Undang-Undang No. 11 tahun 2008 ialah meliputi :

\begin{tabular}{|c|c|c|}
\hline $\begin{array}{c}\text { Jenis Alat } \\
\text { Bukti Digital }\end{array}$ & Informasi Elektronik & Dokumen Elektronik \\
\hline $\begin{array}{l}\text { Bentuk Alat } \\
\text { Bukti Digital }\end{array}$ & $\begin{array}{l}\text { Tulisan; } \\
\text { Suara; } \\
\text { Gambar ; } \\
\text { Peta ; } \\
\text { Rancangan ; } \\
\text { Foto; } \\
\text { Electronik Data Interchange } \\
\text { (EDI) ; } \\
\text { Surat Elektronik (E-mail); } \\
\text { Telegram; } \\
\text { Teleks; } \\
\text { Telecopy; } \\
\text { Huruf; } \\
\text { Tanda ; } \\
\text { Angka ; } \\
\text { Kode Akses ; } \\
\text { Simbol ; } \\
\text { Perforasi ; }\end{array}$ & $\begin{array}{l}\text { Analog; } \\
\text { Digital ; } \\
\text { Elektromagnetik } \\
\text { Optikal ; }\end{array}$ \\
\hline
\end{tabular}

Yang membedakan antara Informasi Elektronik dan Dokumen Elektronik ialah sarana yang dipakai dalam pembuktian alat bukti digital tersebut, sesuai dengan Pasal 1 angka 1, Informasi Elektronik hanya terbatas pada orang yang mampu memahami Informasi yang selanjutnya dapat mengartikan Informasi Elektronik tersebut, sedangkan pada Pasal 1 angka 4 menggunakan sarana komputer dan/atau sistem elektronik untuk menerjemahkan Informasi yang ada dalam Dokumen Elektronik. Yang dimaksud Sistem Elektronik ialah serangkaian perangkat dan prosedur elektronik yang berfungsi mempersiapkan, mengumpulkan, mengolah, menganalisis, menyimpan, menampilkan, mengumumkan, mengirimkan, dan/atau menyebarkan Informasi Elektronik (Penjelasan Pasal 1 angka 5 Undang-Undang No. 11 tahun 2008 tentang Informasi dan Transaksi Elektronik). Sehingga dalam pengungkapan fakta ketiga putusan diatas harus bisa membedakan Informasi Elektronik dan Dokumen Elektronik untuk meminimalisir multitafsir yang mungkin terjadi oleh hakim pengadilan. Dalam Pasal 183 KUHAP "Hakim tidak boleh 
menjatuhkan pidana kepada seorang kecuali apabila dengan sekurang-kurangnya dua alat bukti yang sah ia memperoleh keyakinan bahwa suatu tindak pidana benar-benar terjadi dan bahwa terdakwalah yang bersalah melakukannya”.

Pembuktian menggunakan alat bukti digital, hakim harus bisa mengungkap fakta dan mendapat minimal 2 alat bukti untuk memperoleh keyakinan bahwa suatu tindak pidana benar-benar terjadi dan bahwa terdakwalah yang melakukannya. Hakim Pengadilan Negeri Surakarta Kun Maryoso, S.H, M.H menjelaskan cyber crime merupakan kejahatan dunia maya, pengungkapannya menggunakan alat bukti digital dan saksi ahli yang benar-benar ahli di bidangnya untuk memberikan pengertian tentang peristiwa menurut kacamata ahli, hal ini untuk meminimalkan multi tafsir dengan hakim yang lain karena, kedudukan alat bukti digital ini sebagai petunjuk atau surat dan/atau dokumen elektronik yang dijelaskan dalam UndangUndang No. 11 tahun 2008 tentang Informasi dan Transaksi Elektronik. ${ }^{20}$ Kedudukan alat bukti digital ketiga putusan tersebut sebagai petunjuk atau surat dan/atau dokumen elektronik yang telah dijelaskan dalam Undang-Undang No. 11 tahun 2008 tentang Informasi dan Transaksi Elektronik, sehingga dibutuhkan saksi ahli untuk memahaminya seperti yang dijelaskan pada Pasal 1 angka 1 dan angka 4 Undang-Undang No. 11 tahun 2008 tentang Informasi dan Transaksi Elektronik.

Kasus cyber crime ketiga putusan diatas memerlukan pembuktian guna mengetahui fakta yang terjadi, dalam pengungkapan pembuktian tersebut, Penegak hukum wajib mematuhi prosedur dan ketentuan dalam Hukum Acara Pidana dan Ketentuan dalam Undang-Undang No. 11 tahun 2008 tentang Transaksi dan Informasi Elektronik. Dalam Undang-Undang No. 11 tahun 2008 dalam Pasal 5 ayat 1 "Informasi Elektronik dan/atau Dokumen Elektronik merupakan alat bukti yang sah". Sehingga dalam hal menentukan tentang tata cara pembuktian alat bukti digital Bhudhi Kuswanto, S.H menjelaskan sebagai berikut :

1. Saksi ahli diperintahkan untuk memaparkan tentang pengetahuannya mengenai kasus yang sedang di sidangkan.

2. Kemudian Penyidik dari Polisi wajib menyalin/mengcopy semua isi file dari dokumen atau informasi elektronik tersebut dalam satu perangkat yang baru, kemudian bukti digital tersebut dihadirkan di muka persidangan.

3. Lalu saksi ahli membuat analisis tentang alat bukti digital tersebut untuk menjadi pertimbangan hakim.

Untuk menjaga keaslian dari bukti digital maka penegak hukum mempunyai prosedur sendiri dalam menangani alat bukti digital yang menjadi barang bukti di Pengadilan, Prosedur yang digunakan ialah sebagai berikut :

1. Proses Acquiring dan Imaging

Setelah pe nyidik menerima barang bukti digital, maka harus dilakukan proses acquiring dan imaging yang mengkopi (mengkloning/menduplikat) secara tepat dan presisi 1:1 dari hasil kopi tersebutlah maka seorang ahli forensik dapat melakukan analisis karena analisis tidak boleh dilakukan dari barang bukti digital yang asli karena dikhawatirkan akan mengubah barang bukti.

2. Melakukan Analisis

Setelah melakukan proses Acquiring dan imaging, maka dapat dilanjutkan untuk menganalisis isi data terutama yang sudah dihapus, disembunyikan, di-enkripsi, dan jejak logfile yang ditinggalkan. Hasil dari analisis barang bukti digital tersebut yang akan dilimpahkan penyidik kepada Kejaksaan untuk selanjutnya dibawa ke Pengadilan.

Menurut Bhudhi Kuswanto, S.H, dalam pembuktian alat bukti digital di Pengadilan haruslah memperhatikan keaslian atau originalitas dari alat bukti digital tersebut, karena alat bukti digital ini dapat dirubah sewaktu-waktu dalam hitungan menit, sehingga penyidik di Wilayah hukum Pengadilan Surakarta diharapkan dapat memperhatikan hal itu. ${ }^{21}$

20 Wawancara Kun Maryoso, S.H, M.H, Kamis 28 Agustus 2014, Pukul 11.30 WIB.

21 Bhudhi Kuswanto, Wawancara Pribadi, Pada Hari Sabtu, Tanggal 10 Januari 2015, Pukul 11.30 WIB 
Dalam prosedur pembuktian alat bukti digital di pengadilan ditegaskan pada Pasal 43 ayat (2) Undang-Undang No. 11 tahun 2008 tentang Informasi dan Transaksi Elektronik yang menyebutkan "Penyidikan di bidang Teknologi Informasi dan Transaksi Elektronik sebagaimana dimaksud, dilakukan dengan memperhatikan perlindungan terhadap privasi, kerahasiaan, kelancaran layanan publik, integritas data, atau keutuhan data sesuai dengan Peraturan Perundang-Undangan", Penegak hukum belum sepenuhnya memperhatikan prosedur yang sudah ditetapkan, seperti contohnya pada ketiga putusan diatas, yang rata-rata memberikan kebebasan bagi saksi ahli untuk langsung mengeksplore isi dari alat bukti digital yang berupa laptop, seharusnya penegak hukum sebelum menghadirkan alat bukti digital harus mencopy data dari laptop tersebut ke perangkat yang baru, sesuai dengan prosedur Acquiring and imaging, sehingga meminimalkan perubahan alat bukti yang sedang dihadirkan di Pengadilan dan tidak mengurangi nilai keaslian alat bukti tersebut. Bhudhi Kuswanto menjelaskan bahwa alat bukti digital ini sangat rentan untuk dirubah, bisa saja dirubah dalam hitungan menit tanpa diketahui siapa pun, sehingga sangat disayangkan apabila prosedur yang sudah ada tidak diimplementasikan dalam pembuktian alat bukti digital ini. ${ }^{22}$

Dapat disimpulkan bahwa pemrosesan alat bukti digital pada ketiga putusan tersebut belum sepenuhnya mematuhi prosedur yang sudah digunakan, sangat dimungkinkan adanya perubahan keaslian alat bukti digital yang dihadirkan di pengadilan, tak bisa di pungkiri bahwa tersangka mungkin dikenakan putusan bebas karena, tidak terbukti melakukan suatu hal tertentu karena alat bukti nya sudah dirubah karena, kedudukan alat bukti digital ini mempengaruhi pertimbangan hakim dalam mengambil putusan.

Dari ketiga Putusan yang didapat penulis di lapangan, belum ada pemrosesan alat bukti yang sesuai prosedur, alat bukti digital yang dihadirkan di persidangan telah di explore oleh saksi ahli sebelumnya, sehingga mengurangi keaslian dari sebuah alat bukti itu sendiri, padahal dalam Undang-Undang No. 11 tahun 2008 pada Pasal 43 ayat (2) telah dijelaskan tentang pelaksanaan prosedur penyidikan dalam bidang Teknologi Informasi dan Transaksi Elektronik. Salah seorang Hakim Pengadilan Negeri Surakarta Menjelaskan bahwa dalam penanganan alat bukti, seorang hakim hanya mendengarkan keterangan dari para pihak, salah satunya keterangan saksi ahli yang menjadi pertimbangan hakim dalam membuat putusan, sehingga dalam pemrosesan alat bukti itu sepenuhnya kuasa penyidik. ${ }^{23}$

Jadi ketiga putusan diatas, belum sepenuhnya menggunakan prosedur pemrosesan alat bukti yang benar dari penyidik, sehingga mengurangi keaslian alat bukti digital, karena kedudukan alat bukti ketiga perkara tersebut sangat menentukan putusan hakim. Dalam Undang-Undang No. 11 tahun 2008 tentang Transaksi dan Informasi Elektronik pada Pasal 5 ayat (1) menjelaskan bahwa "Informasi Elektronik dan/atau Dokumen Elektronik dan/atau hasil cetaknya merupakan alat bukti yang sah". Sehingga dalam pemrosesan alat bukti tersebut harus memperhatikan prosedur yang berlaku sesuai Pasal 43 ayat (2) Undang-Undang No. 11 tahun 2008 tentang Informasi dan Transaksi Elektronik.

\section{Kesimpulan}

Sistem pembuktian dan alat-alat bukti berdasarkan Pasal 184 KUHAP mampu menjangkau pembuktian untuk kejahatan cybercrime yang tergolong tindak pidana baru. Penelusuran terhadap alat-alat bukti konvensional seperti keterangan saksi dan saksi ahli, juga pergeseran surat dan petunjuk dari konvensional menuju elektronik akan mampu menjerat pelaku cyber crime. Undang-Undang No. 11 tahun 2008 tentang Informasi dan Transaksi Elektronik pada Pasal 5 telah secara jelas menyebutkan bahwa Informasi Elektronik merupakan alat bukti hukum yang sah berupa informasi elektronik dan/atau dokumen elektronik dan/atau hasil cetaknya.

Bhudhi Kuswanto, Wawancara Pribadi, Pada Hari Selasa, 24 Maret 2015, Pukul 10.30 WIB

Wawancara dengan Kun Maryoso, Kamis Tanggal 28 Agustus 2014, Pukul 11.30 WIB 
Kedudukan alat bukti digital ini mempengaruhi pertimbangan hakim dalam mengambil putusan. Serta sebagai pelengkap alat bukti surat seperti yang dijelaskan pada Undang-Undang No. 11 Tahun 2008 Tentang Informasi dan Transaksi Elektronik. Sehingga dalam pemrosesan alat bukti digital harus di jaga keaslian alat bukti tersebut untuk meminimalisir berubahnya alat bukti digital karena, dapat mempengaruhi proses persidangan. Dari hasil penelitian ketiga Putusan yang didapat penulis di lapangan, belum ada pemrosesan alat bukti yang sesuai prosedur, alat bukti digital yang dihadirkan di persidangan telah di explore oleh saksi ahli sebelumnya, sehingga mengurangi keaslian dari sebuah alat bukti itu sendiri, padahal dalam Undang-Undang No. 11 tahun 2008 pada Pasal 43 ayat (2) telah dijelaskan tentang pelaksanaan prosedur penyidikan dalam bidang Teknologi Informasi dan Transaksi Elektronik.

\section{Daftar Pustaka}

Hiariej, O.S Eddy, 2012. Teori \& Hukum Pembuktian, Jakarta:Erlangga.

Maskun, 2013. Kejahatan Siber Cyber Crime, Jakarta:Kencana Prenada Media Group.

Suhariyanto, Budi. 2012. Tindak Pidana Teknologi Informasi (Cybercrime) Urgensi Pengaturan dan Celah Hukumnya, Jakarta:Raja Grafindo Persada.

Jatimprov, 2014, Tiap Tahun Kasus Cyber Crime Naik 100 Persen,(2-4-2014) dalam http:// www.jatimprov.go.id/site/tiap-tahun-kasus-cyber-crime-naik-100-persen/

Politkum, Pengertian alat bukti yang sah, dalam http://politkum.blogspot.com/2013/05/ pengertian-alat-bukti-yang-sah-dalam.html. diakses pada tanggal 21 Nopember 2014

Samardi, Keterangan Ahli, dalam https://samardi.wordpress.com/tag/keterangan-ahli/ 